\title{
Tingkatan Layanan E-Government Melalui Aplikasi “Monggo Lapor" di Kantor Humas Pemerintah Kota Magelang
}

\author{
Joko Tri Nugraha ${ }^{1}$, Dwi Wahyu Ningsih ${ }^{2}$ \\ 1,2Program Studi Administrasi Publik, Fakultas Ilmu Sosial dan Politik, Universitas Tidar \\ Magelang
}

\begin{abstract}
The low quality of public services provided by the apparatus is a bad image of the government in the community. Problems related to the government are related to the services received by the City Government of Magelang. Electronic government is modern, which facilitates the interaction of government and society in the administration of public government. Through the application monggo report, government relations for the community are used to help with the government and provide advice and criticism about the City of Magelang. The purpose of this study was to analyze the level of e-government services through the application monggo report the field of public complaints and information in the Public Relations of the Regional Secretariat of the City of Magelang. This research uses descriptive qualitative. Data collection methods through observation, interviews and documentation. Data analysis uses an interactive model, by collecting data collection, data reduction, data presentation and conclusion collection. The data validity technique uses triangulation of data and sources. The results showed that the level of e-government services in the form of one-way, two-way communication and transactions was good enough and provided information to the public through websites, social media and online newspapers..
\end{abstract}

Keywords: govenment to citizen, e-government, public service

\section{Introduction}

Dalam kehidupan bernegara Indonesia yang mengisyaratkan adanya amanat agar kesejahteraan untuk khalayak ramai, negara berkewajiban melayani setiap warga negara (citizen) demi tercapainya kebutuhan yang diinginkan oleh setiap warganya. Selain negara yang berbentuk republik, Indonesia merupakan negara yang demokratis. Oleh karena itu, setiap keputusan yang diambil oleh pemerintah harus melibatkan suara terbanyak (Rosyada, 2005).

Di era kemajuan teknologi komunikasi yang berkembang pesat, seperti yang terjadi belakangan ini, sebagian besar orang di negaranegara maju telah mendapatkan akses informasi dari internet dengan sangat mudah dan cepat. Data yang dirilis oleh Real Times Statistics Project, pada awal tahun 2014, pengguna internet telah mencapai 2,5 miliar orang atau 35 persen dari 
jumlah penduduk dunia. Mulai dari individu, perusahaan, sekolah hingga pemerintah pun memanfaatkan akses internet untuk mempermudah urusan sehari-hari. Mulai dari sekedar membaca berita, mendengarkan lagu ataupun berbagai hal yang sedang terjadi di sekitar mereka. Kemungkinan pemanfaatan penggunaan internet yang tidak terbatas pun juga bisa dilakukan oleh pemerintah (Real Time Statistics Project, 2014).

Melihat akses internet yang semakin mudah untuk dijangkau oleh masyarakat, pemerintahan dari banyak negara pun ikut terpanggil untuk memanfaatkan internet. Pemerintah memanfaatkan internet untuk mempermudah proses pertukaran informasi antara masyarakat dengan pemerintah, membantu proses berjalannya pemerintahan, mengadakan rekrutmen dan pengadaan barang, sehingga mempersingkat birokrasi yang ada pada pemerintahan tersebut. Hal ini kemudian berjalan selaras dengan semangat perbaikan informasi dan peningkatan keterlibatan masyarakat pada sistem pemerintahan. Semangat tersebut merupakan semangat turunan dari demokrasi, di mana kebebasan dan partisipasi masyarakat pada sistem birokrasi dan pemerintah menjadi penggerak utama dari berjalannya kehidupan bernegara (Winarno, 2016).

Internet dapat dilihat sebagai alat yang sangat berguna untuk membentuk kembali pemerintahan lokal. Pembentukan kembali ini akan mendorong transformasi nilai-nilai dan paradigma birokrasi tradisional yang menekankan standarisasi, pembagian menurut departemen dan efektivitas biaya operasional, menuju paradigma baru e-government. Paradigma baru tentang $e$ government menekankan tentang pembangunan jaringan yang terkordinasi, kolaborasi dengan pihak eksternal, serta pelayanan kepada pelanggan. Berdasarkan survei singkat tentang situs-situs di beberapa kota di Indonesia dan situs resmi beberapa negara di internet, paradigma baru ini sudah mulai dijalankan. Kota-kota dan negaranegara di dunia tersebut telah mengadopsi sistem "One stop shopping" atau satu pintu, serta orientasi untuk pelanggan melalui desain situs kota-kota tersebut, menekankan kolaborasi dan pembentukan jaringan (Kearny, 2010).

Masalah yang dihadapi pemerintah terkait pelayanan kepada masyarakat juga dirasakan oleh Pemerintah Kota Magelang. Hampir di semua instansi yang berkaitan dengan pelayanan publik menimbulkan keluhan terutama pada proses administrasinya. Meski terkadang di instansi disediakan kotak pengaduan masyarakat, akan tetapi proses penampungan aspirasi tersebut membutuhkan waktu yang lama dalam menanggapi keluhan masyarakat. Bahkan ada juga aspirasi masyarakat yang tidak ditanggapi dengan alasan tidak semua instansi bersifat terbuka sehingga hal itu dinilai kurang efektif. Lemahnya proses pengolahan pengaduan masyarakat secara manual membuat Pemerintah Kota Magelang berinisiatif mengolah pengaduan masyarakat dan informasi dengan cara yang lebih modern dan terpusat melalui aplikasi e-government "monggo lapor". 


\section{E-government merupakan} sebuah garis depan dari rencana pemerintahan untuk mendukung serta menyediakan informasi dan peningkatan pelayanan kepada masyarakat, pelaku bisnis, pekerja pemerintah, unit-unit pemerintahan lain dan organisasi sektor ketiga. $E$ government merupakan rumusan World Bank yang mengacu pada penggunaan teknologi informasi (seperti wide area network, internet dan mobile computing) oleh instansi pemerintah yang memiliki kemampuan untuk mengubah hubungan dengan masyarakat, bisnis dan badan lain dari pemerintah (Lestari, 2015).

Hasil kajian dari Harvard JFK Scholl of Government, untuk menerapkan konsep digitalisasi pada sektor publik, ada tiga aspek penting yang harus diperhatikan dalam penerapan e-government, antara lain: (1) Support, terdiri dari sumber daya finansial, komitmen pemerintah dalam menjalankan program, infrastruktur dan superstruktur pendukung); (2) Capacity, yaitu ketersediaan sumber daya manusia yang cukup, ketersediaan infrastruktur teknologi informasi yang memadai dan; (3) Value, yaitu manfaat yang diperoleh dengan adanya e-government (Indrajit, 2004).

Bagian Humas di Pemerintah

Kota Magelang menyediakan aplikasi website untuk menampung suara rakyat Kota Magelang yang berupa pengaduan maupun saran dan memberikan informasi-informasi mengenai Kota Magelang. Tersedianya ruang untuk menyampaikan aspirasi dalam bentuk pengaduan terhadap jalannya penyelenggaraan urusan pemerintahan dan pelayanan publik akan sangat penting peranannya bagi upaya perbaikan kinerja pemerintah secara keseluruhan.

Dari pengamatan peneliti, terdapat peningkatan penggunaan media sosial oleh masyarakat melalui aplikasi monggo lapor. Media ini mampu menjembatani masyarakat untuk berinteraksi melalui instagram, facebook, twitter, whatsapp, website dan email yang dikelola oleh bagian Humas Sekretariat Daerah Kota Magelang.

Sejak dirilis tahun 2016, pengikut instagram dan facebook monggo lapor sudah mencapai 480, humaspemkotmagelang mencapai 3072 pengikut, twitter laporwalikotamagelang mencapai 282 pengikut dengan berbagai macam postingan dari para pelapor dan informasi seputar Kota Magelang. Pemerintah Kota Magelang juga menyediakan website dengan alamat humas.magelangkota.go.id yang menyediaan berbagai informasi seputar Kota Magelang. Dari penelusuran similiarweb banyaknya pengunjung website Kota Magelang selama enam bulan terakhir sudah mencapai 98.580. Meski termasuk layanan baru, penerapan aplikasi monggo lapor ini banyak membantu masyarakat untuk memberikan aspirasinya dan mendapat informasi seputar Kota Magelang. Penelitian ini mengkaji tingkat layanan $e$ government melalui aplikasi monggo lapor di Sekretariat Daerah Kota Magelang.

Beberapa negara telah menerapkan e-government, meski diakui beberapa negara lainmasih kesulitan dalam menerapkannya. Berdasarkan data dari United Nations E-government, Indonesia masih berada di ranking ke 109 dalam hal 
kemajuan e-government dunia, dan ranking ke 7 di Asia Tenggara di bawah Singapura, Malaysia, Brunei Darussalam, Thailand, Philipina dadn Vietnam. Posisi Indonesia yang masih jauh di bawah negara lain disebabkan antara lain sumber daya manusia yang belum memadai, pembangunan jaringan internet yang membutuhkan anggaran yang besar dan keterjangkauan akses internet di masyarakat. Dampaknya, pemanfaatan teknologi informasi dan komunikasi ini masih belum memberikan dampak bagi peningkatan efisiensi dan efektivitas penyelenggaraan pemerintahan.

Menurut Indrajit (2006), insentif e-government memiliki beberapa arah dan tujuan strategis, antara lain: (1) Dengan e-government, pemerintah ingin memberikan penawaran yang luas mengenai beberapa informasi penting yang dibutuhkan masyarakat dan juga pilihan akses terhadap layanan pemerintah; (2) Mengembangkan transparansi yang lebih luas dalam proses pelayanan publik, karena masyarakat bisa mendapatkan informasi tentang berbagai program dan kegiatan pemerintah serta masyarakat bisa berperan melakukan kontrol dan pertanggungjawaban lebih besar terhadap apa yang dilakukan oleh pemerintah; (3) Dukungan dan partisipasi masyarakat yang lebih luas dalam proses pengambilan keputusan. Partisipasi yang luas akan menjamin keputusan yang diambil memenuhi aspirasi masyarakat menuju proses pemerintahan yang transparan dan demokratis dan; (4) Menggantikan peran dan penyediaan pelayanan kepada masyarakat, di mana mereka bisa mendapatkan informasi dan layanan dengan mendatangi langsung kantor-kantor pemerintahan. Melalui e-government masyarakat mempunyai pilihan akses yang lebih banyak.

Hasil studi yang dilakukan oleh Octavia (2015) menjelaskan lima aspek penting penunjang keberhasilan e-government, antara lain: Pertama, kesiapan sumber daya manusia (SDM). Aparatur pemerintah, baik sebagai pengembang, pengelola maupun pengguna e-government merupakan faktor yang turut menentukan bahkan menjadi kunci keberhasilan pelaksanaan dan pengembangan $e$ government. Karena itu, perlu upaya peningkatan kapasitas sumber daya manusia dan penataan dalam pendayagunaan dengan perencanaan yang matang sesuai dengan kebutuhan, serta pelaksanaannya dilakukan secara bertahap dan berkelanjutan. Hal ini dapat dilakukan melalui pendidikan formal dan non formal maupun pengembangan standar kompetensi yang dibutuhkan.

Kedua, Partisipasi yang diterapkan pada setiap negara sesuai dengan konteks dan jenis demokrasi yang dianut. Demokrasi dalam sistem perwakilan menekankan pada komunikasi atau interaksi antar masyarakat, pemerintah dan pegawai pemerintah dan meningkatkan kesempatan pada masyarakat untuk berpartisipasi dalam proses pembuatan kebijakan sesuai dengan aspirasi masing-masing. Aspek terpenting dari perkembangan $e$ government adalah banyaknya sektor yang terlibat dan saling berinteraksi dalam level yang sama maupun berbeda serta pentingnya proses demokrasi yang bertujuan untuk 
meningkatkan proses pembuatan kebijakan dengan cara meningkatkan kesempatan berpartisipasi semua sektor melalui distribusi informasi dan melakukan komunikasi.

Ketiga, Ketersediaan dan konsistensi anggaran (dukungan pemerintah). Dukungan pemerintah menduduki peran yang sangat penting dalam implementasi $e$ government. Walaupun penggunaan teknologi informasi tidak harus analog dengan kebutuhan dana yang tinggi namun dalam perencanaan kebutuhan pada angaran cenderung terbatas. Keterbatasan pendanaan dalam penerapan e-government bisa berpengaruh pada masih rendahnya kualitas penyelenggaraan pelayanan publik.

Keempat, Keamanan data yang seringkali terabaikan. Dampak kebocoran data akan berdampak sangat buruk terutama menyangkut dokumen birokrasi. Kebocoran data, apalagi jika data tersebut bersifat sangat rahasia, maka akan dimanfaatkan oleh orang-orang yang tidak bertanggung jawab. Pengembangan jaringan sistem informasi yang terintegrasi memungkinkan perlindungan datadata yang tersimpan secara maksimal, sehingga dapat terjaga kerahasiaannya.

Kelima, Infrastruktur. Esensi dasar yang dibentuk oleh $e$ government adalah memfasilitasi masyarakat untuk ikut berpartisipasi dalam program pemerintahan yang rutin. Keberhasilan implementasi $e$ government berkaitan dengan beragam faktor infrastruktur di dalamnya seperti infrastruktur sistem data dan infrastruktur legal atau hukum.
Selain aspek penunjang, beberapa faktor penghambat dalam pengembangan e-government dalam birokrasi pelayanan juga perlu diantisipasi, antara lain: (1) Peopleware (sumber daya manusia) yakni kemampuan para pejabat birokrasi maupun staf dalam menggunakan internet yang masih sangat terbatas. Hal ini terbukti dari masih sangat tergantungnya birokrasi dalam pengembangan e-government terhadap pihak luar; (2) Hardware, yakni berkaitan dengan teknologi dan infrastruktur. Terbatasnya hardware dan software serta masih sedikitnya instansi pemerintah yang terhubung pada jaringan baik lokal (LAN) maupun global (internet) menyebabkan perkembangan $e$ government tidak dapat berjalan lancar dan; (3) Organoware, yakni hambatan birokrasi. Seringkali instansi pemerintah dalam mengoperasionalkan e-government menemui kendala dalam aspek organisasi. Kendala ini ditandai dengan tidak fleksibelnya struktur organisasi dan tata kerja (SOTK) birokrasi yang dapat mewadahi perkembangan baru model pelayanan publik melalui e-government (Novita, 2014).

\section{Metode Penelitian}

Penelitian ini menggunakan metode kualitatif dengan pendekatan deskriptif, dengan menyajikan fenomena sosial dan fakta alamiah di lapangan untuk diilustrasikan secara utuh (Patton, 2002). Teknik keabsahan data menggunakan metode triangulasi dengan cara mengecek kebenaran data atau informasi yang diperoleh peneliti dari berbagai sudut pandang yang berbeda dengan mengurangi 
sebanyak mungkin perbedaan yang terjadi pada pengumpulan dan analisis data (Sugiono, 2014). Teknik pemilihan informan menggunakan teknik purposive sampling (Sugiono, 2009). Metode pengumpulan data dalam penelitian ini menggunakan wawancara, observasi serta dokumentasi. Sementara teknik analisis data menggunakan model interaktif dengan tahapan pengumpulan data, reduksi data, penyajian data dan penarikan kesimpulan (Sugiono, 2014).

\section{Hasil dan Pembahasan}

Publish (Komunikasi Satu Arah)

Publish merupakan tahapan yang menggunakan teknologi informasi untuk meluaskan akses untuk informasi pemerintah dan informasi untuk masyarakat atau publik sebagai sarana yang memudahkan dalam memberikan pelayanan e-government yang maksimal. Dalam hal ini, publish merupakan tingkatan komunikasi yang bersifat satu arah di mana tidak terjadi feedback atau respon dari narasumber.

Aspek pertama dari publish adalah informasi. Pemerintah memiliki kewajiban untuk memberikan informasi kepada masyarakat melalui media penyebaran informasi terkecuali jenis informasi yang mendapatkan pengecualian oleh undang-undang informasi, merupakan sesuatu yang dibutuhkan oleh semua orang khususnya warga masyarakat Kota Magelang. Masyarakat membutuhkan informasi yang akurat dan terpercaya seputar kondisi Kota Magelang seperti berita aktual, acara Kota Magelang, kegiatan pemerintahan
Kota Magelang dan proyek pembangunan di Kota Magelang.

Sumber informasi seputar Kota Magelang dikelola khusus oleh bagian Humas Sekretariat Daerah Kota Magelang melalui media website dan juga media sosial seperti facebook dan instagram. Informasi tentang pemerintahan dapat diakses oleh masyarakat pada website resmi humas.magelang.kota.go.id dengan memanfaatkan koneksi internet baik menggunakan android maupun komputer atau laptop.

Media lain untuk mempublish informasi adalah koran online yang langsung dapat diakses oleh masyarakat. Humas Sekretariat Daerah kota Magelang menyediakan informasi seputar Kota Magelang melalui koran online magelangekspres.com yang menyajikan informasi seperti politik, kriminalitas, olahraga, cuaca dan berita lainnya.

Aspek kedua dari publish adalah daftar pengaduan masyarakat yang dipublikasikan di media sosial sebagai bahan informasi untuk semua masyarakat Kota Magelang. Pengaduan masyarakat yang ditampilkan biasanya tentang pembangunan fisik di area Kota Magelang, misalnya tentang prasarana jalan yang rusak. Humas juga mempublikasikan pengaduan masyarakat terkait instansi yang menyediakan pelayanan publik seperti PDAM, PJU, DLH dan lain sebagainya. Jika ada masyarakat yang tidak ingin identitasnya diketahui oleh orang banyak, dapat mengirimkan pengaduan melalui nomor WhatsApp, email dan surat secara manual.

Interact (Komunikasi Dua Arah) 
Pada tahapan interaksi, terjadi komunikasi dua arah antara pemerintah danmasyarakat yang berkepentingan. Pemerintah dan masyarakat saling memberikan respon demi tujuan tertentu. Aspek pertama dari tahap interaksi ini adalah merespon setiap pengaduan dari masyarakat.

Di bagian Humas Sekretariat Daerah Kota Magelang, pengaduan yang dikirimkan oleh masyarakat secepat mungkin langsung direspon, meskipun hanya sekedar mengucapkan terimakasih atas pengaduan yang disampaikan. Pengaduan yang disampaikan oleh masyarakat oleh pihak Humas Kota Magelang akan langsung direspon akan tetapi ada yang tidak langsung ditangani saat itu juga karena ada hal yang membutuhkan perencanaan dan dana dalam proses perbaikan. Respon yang cepat biasanya melalui nomor WhatsApp.

Aspek kedua tahap interaksi adalah penanganan pengaduan terhadap instansi terkait. Humas Pemerintah Kota Magelang merupakan bagian pengelola pengaduan dari masyarakat. Tugas utama humas yaitu menyampaikan kepada instansi yang terkait masalah dari masyarakat melalui surat, WhatsApp dan email.

Pihak humas bekerja sama dengan instansi-instansi di Kota Magelang, sehingga setiap penyaluran pengaduan dari masyarakat selalu mendapatkan respon yang cepat dari instansi terkait. Penyelesaian masalah berupa laporan pembangunan fisik dari masyarakat harus menunggu perencanaan dan anggaran yang jelas.

Transact (Transaksi)
Pada tahapan transaksi, telah terjadi interaksi dua arah seperti pada tahap interaksi, hanya saja terjadi sebuah transaksi yang berhubungan dengan perpindahan uang dari satu pihak ke pihak lainnya. Pemerintah memiliki kewajiban untuk memberikan pelayanan yang maksimal tanpa memberatkan masyarakat.

Sama halnya dengan bagian Humas Sekretariat Daerah Kota Magelang yang memberikan layanan informasi dan pengaduan masyarakat tanpa memungut biaya sedikitpun dari masyarakat Kota Magelang. Misalnya pengaduan tentang sampah yang lama tidak kunjung diambil. Mendasarkan wawancara dengan salah satu informan dengan melaporkan melalui akun facebook monggo lapor, tidak membutuhkan waktu yang lama, langsung ditangani oleh Humas yang kemudian diteruskan ke Dinas Lingkungan Hidup (DLH) dan pagi harinya sampah di depan rumah langsung diambil oleh petugas DLH.

\section{Kesimpulan}

E-government merupakan salah satu upaya pemerintah untuk mendekatkan pelayanan kepada masyarakat. Implementasi layanan pemerintah secara elektronik dapat meningkatkan produktivitas serta efisiensi para birokrat. Dengan tingkat layanan publish, interaksi dan transaksi di Humas Sekretariat Daerah Pemerintah Kota Magelang, masyarakat mampu menyampaikan pendapat-pendapat mereka tentang pemerintahan yang sedang berjalan dan bahkan dalam tingkat integrasi yang lebih jauh, masyarakat bisa terlibat langsung dalam proses pembentukan kebijakan publik. 


\section{References}

Indrajit, Richardus. E. (2004) Egovernment Pembangunan Strategi dan Pengembangan Sistem Pelayanan Publik Berbasis Teknologi Digital, Andi Offset: Yogyakarta.

Indrajit, Richardus, E. (2006) Electronic Government, Andi: Yogyakarta.

Lestari, Puji Umi Pratiwi dan Permata Ulfah. (2015) Identifikasi Faktor Organisasional dalam Pengembangan E-Governance Padad Organisasi Pengelola Zakat, Jurnal Mimbar, Vol. 31, No. 1.

Novita, Dien. (2014) Faktor-Faktor Penghambat Pengembangan EGovernment: Studi Kasus Pemerintah Kota Palembang, Sumatra Selatan. http://www.ejournal.com, Jurnal Eksplora Informatika, Vol. 4, No. 1.

Octavia, Ayu Aditya. (2015) EGovernment Pada Kantor Pelayanan Pajak Pratama dalam Pemberian Pelayanan di Kota Bontang, E-Journal Pemerintahan, Vol. 3 No. 3.

Patton, Michael Quinn and Michael Cichran. (2002) A Guide to Using Qualitative Research Methodology, UK: Medicins Sans Frontieres.

Real Time Statistics Project. (2014) Internet Usage and Social Media Statistics, http://www.internetlivestats.com, diakses pada Juni 2014.

Rosyada, Dede. (2005). Demokrasi Hak Asasi Manusia dan Masyarakat
Madani, Time Ice UIN Jakarta, Jakarta: Kencana Prenada Media Group.

Sugiono. (2009) Metode Penelitian Bisnis (Pendekatan Kuantitatif, Kualitatif dan $R \& D)$, Alfabeta: Bandung.

Sugiono. (2014) Metode Penelitian Manajemen, Alfabeta: Bandung.

Winarno, Budi. (2016) Kebijakan Publik Era Globalisasi (Teori, Proses dan Studi Komparatif), Yogyakarta: CAPS. 